\title{
The COVID-19's Economic Crisis and Its Solutions: A Literature Review
}

\author{
Andi Irawan ${ }^{1 *}$, Halim Alamsyah ${ }^{2}$ \\ 'Agribusiness Department, Universitas Bengkulu, Indonesia \\ ${ }^{2}$ Lembaga Penjamin Simpanan, Indonesia \\ E-mail: 'andiirawan@unib.ac.id, ${ }^{2}$ halim6002@gmail.com
}

${ }^{*}$ Corresponding Author

\section{JEL Classification:}

E60

E66

Received: 09 August 2020

Revised: 30 October 2020

Accepted: 04 November 2020

\begin{abstract}
The pandemic of COVID-19 predicts can create a global economic crisis include Indonesia. This paper aimed to answer the first question: how the transmission process from a pandemic became an economic crisis; Second, what macroeconomic policies should take to recover the economic crisis of the COVID-19 pandemic; third, what non-economic measures must consider confirming the macroeconomic policies achieved its target. Using 32 references in the literature review process, we tried to find out the answers to this study's questions. This study recommended that the measures for containment of the virus spread and the execution of fiscal and monetary stimulus should be coordinate internationally among countries and territories.
\end{abstract}

Keywords:

Covid-19, economic crisis, macroeconomic policy

\section{How to Cite:}

Irawan, A., \& Alamsyah, H. (2021). The Covid-19's Economic Crisis and Its Solution: A Literature Review. Etikonomi, 20(1), 77 - 92. https://doi.org/10.15408/etk.v20i1.16870. 


\section{Introduction}

On December 31, 2019, China revealed that some mysterious pneumonia cases had emerged in Wuhan City, Hubei Province. On January 7, 2020, Chinese authorities announced the detection of the latest human virus, Betacorona, named as 2019-nCoV by the World Health Organization (WHO), which was later named SARS-CoV-2 cause of the Pneumonia outbreak in Wuhan. On January 10, 2020, the viral genome was released and published officially as COVID-19 by WHO (Marty \& Jones, 2020).

The impact of COVID-19 spreads the entire world quickly. Since May 7, 2020, WHO noted this virus had infected 215 areas, territories, or countries in the world within five months of being predicted its existence. When referring to the number of confirmed cases, deaths, and the duration of outbreaks, COVID-19 has the worst impact compare to other pandemics (see Table 1). For instance, COVID-19 spreads in 215 countries compared to other pandemics that spread in less than 30 countries. COVID-19 also is known as more dangerous than the previous pandemics, such as MERS (396 times as many victims), SARS (328 times as many victims), and Ebola (119 times as many victims).

Table 1. The Cases of Infection, Death and Area Distribution of The Pandemic of COVID-19 Compared by Other Pandemics

\begin{tabular}{|c|c|c|c|c|c|}
\hline Pandemic & $\begin{array}{l}\text { Confirmed } \\
\text { cases }\end{array}$ & $\begin{array}{l}\text { Confirmed } \\
\text { death }\end{array}$ & $\begin{array}{c}\text { Area and } \\
\text { started date }\end{array}$ & $\begin{array}{l}\text { Number of } \\
\text { countries, areas, } \\
\text { or territories } \\
\text { with cases }\end{array}$ & $\begin{array}{c}\text { Time duration of } \\
\text { cases }\end{array}$ \\
\hline $\begin{array}{l}\text { COVID-19 } \\
\text { (SARS-CoV-2) }\end{array}$ & 3679499 & 54199 & $\begin{array}{l}\text { Wuhan (China), } \\
31 \text { December } \\
2019\end{array}$ & 215 & $\begin{array}{l}\text { December-May } \\
2020 \text { (temporary } \\
\text { calculation) }\end{array}$ \\
\hline $\begin{array}{l}\text { Middle East } \\
\text { Respiratory } \\
\text { Syndrome } \\
\text { (MERS) }\end{array}$ & 2494 & 858 & $\begin{array}{l}\text { Saudi Arabia, } \\
\text { April } 2012\end{array}$ & 27 & April 2012-Nov 2109 \\
\hline SARS & 8096 & 774 & $\begin{array}{l}\text { Vietnam, } 26 \\
\text { February } 2003\end{array}$ & 29 & $\begin{array}{l}26 \text { Feb - } 31 \text { Dec } \\
2003\end{array}$ \\
\hline Ebola & 3462 & 2134 & $\begin{array}{l}\text { North Kivu } \\
\text { Province, } \\
\text { Democratic } \\
\text { Republic of } \\
\text { Congo }\end{array}$ & $\begin{array}{c}\text { Central and West } \\
\text { Africa }\end{array}$ & $\begin{array}{l}\text { The first outbreak in } \\
\text { remote villages in } \\
\text { Central Africa 1976, } \\
\text { Outbreak in 2014- } \\
2016 \text { West Africa as } \\
\text { complex and the } \\
\text { largest one }\end{array}$ \\
\hline
\end{tabular}

Source: Authors' compilation from World Health Organization

Coronavirus pandemic predictions can stimulate the economic crisis. The latest OECD Economic Outlook projects annual global GDP growth to fall from 2.9 percent in 2019 to 2.4 percent in 2020, with GDP contracting in the first quarter of 2020. GDP growth in China is predicted below 5 percent this year. China's latest data shows that the industrial production index falls to 13.5 percent in the first two months of 
2020, the most dramatic decline since the early 1990s. Meanwhile, the prediction state that the spread of a pandemic in Europe and the US can create stagnation or recession throughout Europe, with a significant reduction in growth, which could reach 5 percent. The most vulnerable European region is Southern Europe (Lucchese \& Pianta, 2020).

Based on the previous pandemic relationship with the economy, we can know that the pandemic creates a strong regional negative externality. During the Ebola outbreak, although its spread was limited in Africa, mainly it only occurred in three West African countries, with a relatively small number of cases such as Nigeria (20 cases), Mali (8 cases), and Senegal (1 case) and all of the cases quickly control. However, the negative impact turned out to hit the whole economy of Sub-Saharan Africa. This condition happens because of weakening consumer and investor confidence and disruption of tourism and cross-border trade. According to a World Bank report, the cumulative losses of SubSaharan Africa countries (not include the three countries directly affected by the Ebola virus) in 2015 exceeded $\$ 500$ million as the worth of negative externality of Ebola. This phenomenon is similar to the SARS outbreak in 2003. The Asian Development Bank (ADB) in early May 2003 estimated that GDP growth in East and Southeast Asia was reduced by 0.2 percent due to disruptions in the tourism, catering, hotel, retail, and other industries throughout Asia as the negative impact of the SARS pandemic (Gong et al., 2020).

Table 2. Impact of COVID-19's Pandemic on The Economic Growth of Indonesia and The World

\begin{tabular}{|c|c|c|c|c|}
\hline \multirow{3}{*}{$\begin{array}{c}\text { Country and } \\
\text { Territory }\end{array}$} & \multicolumn{4}{|c|}{ Economic growth (percentage) } \\
\hline & \multirow{2}{*}{$\begin{array}{c}\text { Before } \\
\text { COVID-19 } \\
2019\end{array}$} & \multicolumn{2}{|c|}{ Impact of COVID 19} & \multirow[b]{2}{*}{ Referred institution } \\
\hline & & 2020 & 2021 & \\
\hline \multirow{4}{*}{ Indonesia } & \multirow{4}{*}{5,02} & $-3.5-2.1$ & $5.2-5.6$ & World Bank \\
\hline & & 2.5 & 5 & Asian Development Bank (ADB) \\
\hline & & 3 & 4.3 & Moody's \\
\hline & & 0.5 & 8.2 & IMF \\
\hline China & 6.1 & 1.2 & 9.5 & \\
\hline India & 4.2 & 1.9 & 7.4 & \\
\hline ASEAN-5 & 4.8 & -0.6 & 7.8 & \\
\hline USA & 2.3 & -5.9 & 4.7 & \\
\hline Euro Area & 1.2 & -7.5 & 4.7 & \\
\hline
\end{tabular}

Source: (Kementerian Keuangan, 2020)

Prediction states that COVID-19 negatively affects both global and country economic growth (Table 2). China's economic growth plummeted from 6.1 percent (2019) to 1.2 percent (2020), India fell from 4.2 percent to 1.9 percent, ASEAN-5 dropped from 4.8 percent to -0.6 percent, the USA from 2.3 percent to -5.9 percent, 
the Euro Area down from 1.2 percent to -7.5 percent. The number of predictions about the impact of COVID-19 on the Indonesian economy presents the same results. The results show that Indonesia has a decline in growth, i.e., from 5.02 percent in 2019 and plummet become -3.5 to 2.1 percent in 2020 according to the World Bank, down to 2.5 percent according to the Asian Development Bank, decrease to 3 percent (according to Moody's), and decrease to 0.5 percent based on IMF prediction in 2020 (Kementerian Keuangan, 2020)

The exciting facts related to the forecasts of the impact of COVID-19 as previously showed the phenomena that all countries and regions whose growth decline in 2020, return their level of economic growth which the same as to the level before pandemic in 2021 or even they have higher economic growth than 2019 (before COVID-19 pandemic). This fact means that these forecasts assume the shape of economic recovery in the $\mathrm{V}$-shape where the economy plummeted because the pandemic can immediately recover to the initial conditions (before the pandemic).

The economic crisis of COVID-19 is an unprecedented phenomenon because of some reasons as follows: 1) as described in Table 1, the spread and the victims of COVID-19 are geographically broader and more significant in the number of victims than previous pandemics so that the economic crisis which happened become global and worse in both its magnitude and duration. If the previous epidemic's impact impacted the country and regional coverage, then the economic crisis of COVID-19 is predicted a truly global impact. 2) The previous significant economic crises, namely the Asia Pacific crisis in 1997-1998 and the world financial crisis in 2008, are caused by economic factors. Massive capital outflows from the Southeast Asian region affect the Asia Pacific crisis (Irawan, 2005). The problem in the US subprime mortgage market affects the 2008 financial crisis (Crotty, 2009). Meanwhile, the COVID-19 economic crisis is due to the non-economic factor. Thus, to overcome the economic crisis caused by this pandemic, it must be understood how a COVID-19 pandemic phenomenon can turn into an economic crisis. This condition is the first question that will be answered in this study. Policymakers for keeping the number of infected people must handle two things by national health facilities. First, slow down the virus's spread through physical distancing, use masks, and regularly wash the hands. Second, measures are taken to block the spread of the virus, such as a lockdown or closing activities that have implications for gathering people and quarantine the territories. Meanwhile, in terms of overcoming the economic recession or depression, based on the experience of the previous economic crises, including the great depression in the 1930s, the Keynesian macroeconomic policy was the choice (Herrero, 2020), namely by taking expansionary fiscal and monetary policies. However, fiscal and monetary policy to overcome the pandemic must consider the domestic and global conditions (Zhao et al., 2020). For this reason, the second and third questions of this study to be answered are what macroeconomic policies should be taken to recover the economic crisis of the COVID-19 pandemic and what noneconomic measures must be considered to help the macroeconomic policies achieved their target, i.e., the economic recovery. 
This paper is a preliminary study to understand the impact of the COVID-19 pandemic on the Indonesian economy. This study will contribute as follows: First, to give policymakers a complete picture of economic policies that are important to overcome the destructive economic impact of the COVID-19 pandemic and the non-economic requirement that must be fulfilled to achieve economic recovery. Second, this study can be an essential reference for the next researchers who will empirically verify the impact of COVID-19 on the Indonesian economy and simulate economic policy's economic recovery effect.

\section{Methods}

To answer the three questions of this study, we applied the following methods: First, searching for references from the Internet used keywords, i.e., pandemic, COVID-19, economic crisis, and macroeconomic policy. We have collected about 170 references that suit the keywords. Second, from the 170 initial references, we selected 32 among them because they related to issues that were fulfilled as reference for this study, i.e., research about economic predictions of COVID-19 impact on the country, region, and even global coverage. Second, the empirical impact of the previous epidemic -such as AIDS and Ebola- is a benchmark to estimate the impact of the COVID-19 pandemic on the economy. Third, reports from government and international institutions regarding the economic impact of COVID-19 on the economy. Fourth, Researches related to health management to reduce the spread of the pandemic, either directly related to COVID-19 or other diseases such as AIDS and Ebola. Fifth, researches related to the economic crises in Indonesia. Through using 32 references in the literature review process, we find out the answers to the questions of this study.

\section{Discussion}

\section{From Pandemic to Economic Crisis}

Theoretically, how a pandemic transmission becomes an economic crisis show in Figure 1. It assumes that there are two categories of goods and services: essential goods and services. Example goods and services use for containment the viral infection (such as food, ventilators, masks, hand sanitizers, doctor and paramedics services) and other goods and services are categorized as non-essential ones because they do not play an essential role in dealing with stopping viral infections.

Three panels in Figure 1 reflect the impact of COVID-19 on both essential and non-essential of goods and services market and GDP. In panel (a), the initial equilibrium situation for essential goods and services is at point E1, where the equilibrium quantity is Q1, and the market price at equilibrium is P1. During the pandemic, the demand for essential goods and services such as food and medicine rise significantly. In panel (a), shifting the demand curve from D to D1 reflects the increase in demand for essential goods and services; the shifting effect of the demand is that the price of essential goods rises from $\mathrm{P} 1$ to $\mathrm{P} 2$, and the amount of traded goods rises at Q2. 
When the demand for essential goods such as medical equipment and medicines increases, many non-essential goods switch to producing these essential goods, something similar happened in Indonesia. Significant increase in the number of health equipment manufacturers for containment COVID-19 as data showed on April 4, 2020, compared to data on February 29, 2020. Mask manufacturers increased 77 percent (from 22 producers on February 29, 2020, to 39 producers on April 4, 2020). The highest increase in the personnel protective equipment industry, i.e., raising its producers by 567 percent from three manufacturers in February, became 20 manufacturers in April 2020. An increase of 186 percent occurred in the hand sanitizer producer from previously only 36 manufacturers to 103 manufactures.

Then, there was an increase in imports of these essential goods in the pandemic's economic regions. As a result, supply increased slightly in response to this increase in demand, shifting the supply curve from $S$ to $S 1$. This supply curve shift is not too large for two reasons. First, shifting from non-essential goods to essential goods (for instance, from car to a ventilator) happened. However, the company that has just turned to produce these essential goods does not have the quality of technology, skills, and experience to produce these essential goods in large quantities as same as the quality of technology of the regular company that usually produce these goods in a situation before the pandemic. Second, import demand for essential goods such as health equipment has also increased globally because this epidemic has gone global (demand for imports of medical supplies such as masks, ventilators, testing kits, and protective equipment personnel has increased in all countries across the world). This increase in supply causes a new equilibrium market at E3 where the quantity of goods is traded, Q3, and its price, P3, which is lower than P2. The equilibrium price, P3, is higher than P1 (market equilibrium price when normal conditions or without a pandemic).

Panel (b) illustrates the market's reaction to supply and demand changes in nonessential goods markets because of the pandemic. A pandemic causes a decrease in demand for non-essential goods such as cars. Panel (b) shows the initial position of the non-essential goods market equilibrium at E4, where the quantity traded is Q4 and the price, P4. Demand drops sharply and graphically showed by shifting the demand curve from D to D1, price fall from P4 to P5, and the quantity traded falls from Q4 to Q5. Due to the closure of businesses and factories of these non-essential goods permanently or temporarily, many producers leave the market. This phenomenon reduces the supply of non-essential goods. Two factors, i.e., 1 caused the drop in supply) Many non-essential goods producers turn to produce essential goods (for example, General Motors in the USA). The drop in demand for non-essential goods that occurred globally caused the demand for these goods' exports also plummet. The supply cut in panel (b) indicates a shift in the supply curve to the left from $S$ to $S 1$. This shift causes a slight increase in prices, i.e., at P6 with the number of goods traded at Q6. The price of P6 is still lower than the initial price, $\mathrm{P} 4$, because the drop in demand prevents the price from returning to the initial level (P4). 


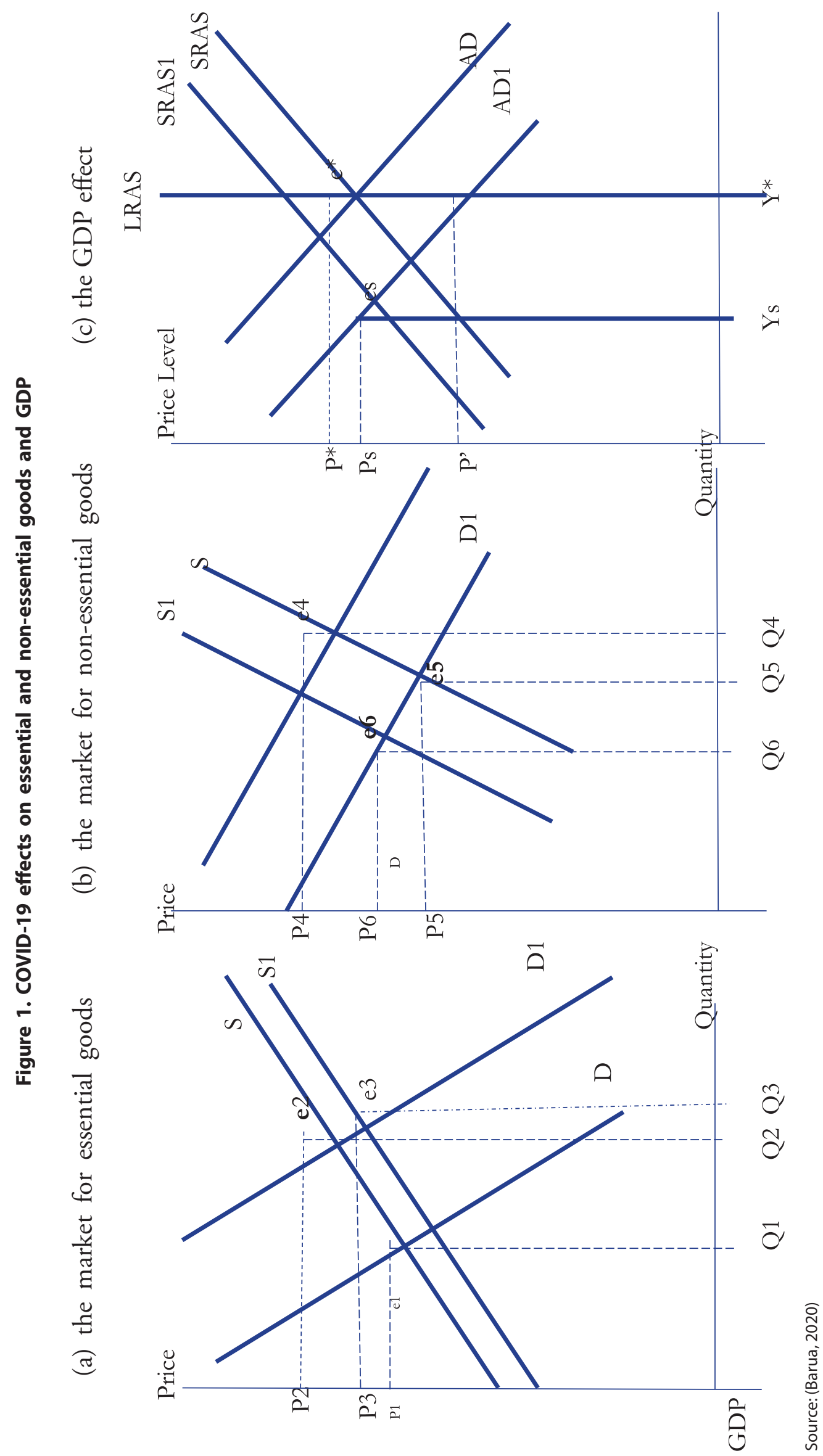


Panel (c) illustrates the process of how pandemic becomes to recession through the AS-AD curve. In the initial situation, at AD-AS, long-run full-employment equilibrium. Goods and services assumed in the economy are classified as essential goods and services (personnel protection equipment, ventilators, masks, hand sanitizers, doctors, health and hospital services, and food) and non-essential goods and services (all goods and services that have no contribution to protecting our selves from COVID-19 infections).

The virus's direct effect is the increasing number of infected people and fatalities, thus requiring the government or the community to take containment and mitigation actions (World Bank, 2020). The closure of business activities and workers unable to work in factories and other workplaces, trade and business disruption also occurs as a result of losing access to goods, travel bans, and restrictions on the entry of goods, people, and other capital generate disruption aggregate supply (Asian Development Bank, 2020). This disruption is shown graphically by shifting the short-term AS curve to the left, i.e., from SRAS to SRAS1.

In the short term, the pandemic also causes aggregate demand disruption. This aggregate demand disruption refers to the experience of Sub Saharan Africa due to: 1) Disruption of trade and value chains, which then suppresses commodity exports; 2) decreasing foreign financing (foreign direct investment, foreign aid, remittances, tourism revenue, and capital flights) (World Bank, 2020). Meanwhile, according to the Asian Development Bank (2020), aggregate demand disruption occurs due to a sharp and temporary decline in consumption and investment in China and other countries affected by the pandemic. Spillover from the drop of aggregate demand is transmitted to other sectors and economies through trade and production.

The impact of the negative shock on both AD and AS causes the economy to be at es where GDP (output), Ys smaller than full-employment output, $\mathrm{Y}^{*}$ and Ps, price levels are lower than full-employment price levels $\left(\mathrm{P}^{*}\right)$. This condition means that the economy in a short-run condition likely face lower national output (income) coupled with deflationary pressure. If this phenomenon continues, it will create an economic recession.

Furthermore (Sachs, 2020) explained that there could be mutual interactions between aggregate demand and supply shock. When containment measures occur, such as lockdown, it implies weakening the circular flow of income. When household spending decreases and the economy in an uncertain situation causes a decrease in demand, it affects the company by losing its revenue. After that company ran out of cash to pay labor wages, this situation becomes further pressure on household spending. This situation is meaning supply shock induces the demand and vice versa. Another domestic impact of the lockdown creates unprecedented capital outflow from emerging markets that halved the company's value. This condition is also associated with the depreciation of the domestic exchange rate that impacts rising prices of imported goods. Nevertheless, exports also plummeted because export goods produced by emerging countries such as Indonesia have links to disrupted global supply chains. This turbulence can continue in the future until the COVID-19 spread is successfully locked. 
In the long run, if the economy can restore its output (indicated by the SRAS1 curve shifting to SRAS) but fails to increase aggregate demand, then the economy is in a situation where GDP is at $\mathrm{Y}^{*}$ but the price level will continue to fall at P' (see panel c, Figure 1). This situation suggests, in the long run, should come with a significant and upward demand shock. In this situation, the importance of the monetary and fiscal policy's existence to shift the $\mathrm{AD}$ curve to its position before the crisis.

\section{Lessons from the Previous Pandemics}

The study of past epidemics identified several channels through which economic costs can arise. Loss of labor productivity through death and illness was an important channel, especially in severe pandemics, such as in the case of the 1918 influenza. Economic costs also arose due to weak consumer sentiment, high exposure to the service sector, the impact of social distancing, and potential financial amplification. All the channels that caused these economic costs to arise still relevant in today's case for the COVID-19 pandemic (Boissay \& Rungcharoenkitkul, 2020).

Several insights from the previous pandemics explained as follows; first, estimates of the economic cost of epidemics vary widely, depending on the severity and treatment. Influenza 1918 is generally the costliest pandemic in modern history. Correia et al. (2020) estimate that this pandemic curtailed manufacturing activity by about 20 percent. While Barro et al. (2020) estimated the negative impact of this pandemic on global GDP. Social distancing measures were introduced to contain the 1918-influenza pandemic, but these vary between jurisdictions, and there was no synchronous halt in economic activity. Correia et al. (2020) found that states in the USA that introduced containment measures earlier got relatively higher medium-term growth. This phenomenon showed that, at that time, the economic costs were mainly due to loss of lives, which was spread for three years (see also Fan et al., 2016). Many studies have estimated the hypothetical cost of the 1918 influenza pandemic in the modern era. GPMB (2019), for example, estimated the economic cost of 1918 influenza has a value of about 5 percent of global GDP. The milder pandemics showed a lower economic cost. The estimated economic cost for the SARS epidemic is merely 0.1 percent of global GDP (Lee \& Mckibbin, 2004). The economic costs of the H1N1 "bird flu" and Ebola epidemics are also relatively small. The economic costs for the H1N1 pandemic have a value of 0.1 percent of global GDP. Meanwhile, Ebola merely reduced the GDP growth in Guinea by 2 percent, Liberia by 3.4 percent, and Sierra Leone by 3.3 percent, respectively (World Bank, 2014).

Second, economic costs can manifest through both supply and demand effects. In response to pandemic risk, workers limited their social interactions by reducing labor supply and consumption. Arnold et al. (2006) examined the supply side channel in the influenza 1918 pandemic. They concluded that, in the first year, this pandemic reduced GDP by about 2.3 percent. The same study has been done related to SARS to assess the demand-side. This study assumed the severe effects of the pandemics were in industries whose products required collected customers. They found out that overall demand-side effects would reduce GDP by 2 percent. 
Third, pandemics have long-term adverse effects on the economy. On the supply side, in the 1918-influenza pandemic, the most expensive costs were mortality and workforce reduction. A one-time reduction in the labor force will increase the ratio of capital to labor and decrease the return rate on capital and lower the rate of capital accumulation and GDP growth over the years (Fan et al., 2016).

Pandemics can also cause a continuous decline in total demand. Jordà et al. (2020) studied the long-term effects of 12 major European epidemics dating from the 14th century. They found that the pandemics are usually followed by decades of low natural interest rates due to high precautionary saving and reduced investment opportunities. Indeed, unlike war, pandemics do not destroy physical capital and usually result in a prolonged surplus capital per surviving worker.

There is a good lesson from previous pandemics studies that are still relevant to the COVID-19 case. If the epidemic reaches a global scale with many fatalities, the economic losses will also be very high and persistent. It means that containment measures are needed, although expensive from economic costs, because they give economic benefits in preserving the workforce. Besides that, these measures will save human lives as the ultimate goal to handle pandemics. The COVID-19 pandemic is different from previous ones for the following reasons: first, the global spread of Covid-19 is faster than previous ones due to the international integration of markets and regions. Second, asymptomatic carriers have caused the transmission of COVID-19 faster than previous ones, such as SARS. This situation led to a large-scale lockdown policy implemented globally in an almost synchronous manner (Boissay \& Rungcharoenkitkul, 2020). Then, this phenomenon caused a sudden stop in global economic activity that had implications for the recession and, more than that, a crisis of the economy.

\section{Economic Recovery of COVID-19's Pandemic}

According to Szlezak et al. (2020), the shape of the economic recovery process of the COVID-19 pandemic will result in four recovery patterns, namely; 1) V-shape. The pandemic caused the plummeting economy, marked by both a sharp decline in economic growth and increased unemployment, but the economy could recover back to the pre-crisis position in a short time. 2) U-shape, Growth dropped dramatically, and unemployment increased. The rate of economic growth recovery takes a long time. The gap between the old and new economic growth paths remains large, which shows damage in the supply side of the economy, mostly lost output, and requires a much longer time to return to pre-crisis conditions, 3) L-shape, as the worst shape. The country's economic growth has never been restored to its output before the crisis, but its growth rate has declined. The distance between the old and new paths of growth is widening, with continuing output lost. This condition means that the crisis has left permanent structural damage on the supply side. This L-shape is the worst damaging form due to the pandemic economic crisis, 4) W-Shape, multiple, or repeated V-shape. This shape can happen because of a second (third and so on) wave outbreak. This shape is also classified as a bad form of a country's economic recovery process. 
The study of Boston Consulting Group shows that most company leaders worldwide predict a pessimistic recovery of the world economy because 51 percent of them predict the pattern of economic recovery is U-shape, 25 percent L, and 16 percent W-shape. Only 8 percent of those assess the process of economic recovery with optimism, i.e., having V-shape. There is a common prediction that the COVID-19 crisis has large economic damage.

The difficulty in overcoming COVID-19's macroeconomic crisis lies in the magnitude of the uncertainty within it. The first uncertainty is how long the virus confinement. It is known that restrictions on the human population's movement and activities have an essential role in suppressing viral infections, but there is no certainty how long the confinement should be ended because confinement has contributed to economic recession. The tighter the act of containment is for saving human lives, the harder recession experienced by the economy (Eichenbaum et al., 2020).

The absence of a similar historical precedent to the previous economic crisis case make the economic crisis of CORONA also can be classified as an unprecedented and complicated economic crisis (Bank of Spain, 2020). At the same time, Boissay \& Rungcharoenkitkul (2020) said an essential difference between COVID 19 and previous pandemics such as SARS, MERS, and flu. In the current situation, the bad impact of Coronavirus more dangerous than the pandemic before for at least two reasons, i.e., 1) international integration in the COVID-19 era is more significant than previous pandemics so that making pandemic spread more globally too and 2) the presence of transmission factors can occur by carriers without symptoms which causes faster transmission compared to previous pandemics.

According to Herrero (2020), a pandemic's economic impact depends on how it is handled from a health and economic perspective. There are two measures for overcoming a pandemic. The first, mitigation, focuses on slowing down but not always stopping the spread of the virus. The purpose of mitigation measures is to reduce the demand for health care so that all virus victims can still be managed by a country's health infrastructure while protecting those most risk people. The second, suppression, aims to reverse the pandemic's growth, but its risk is a pandemic could rebound at any time when suppression measures are stopped. Mitigation actions cause the pandemic existence longer but have a less extreme economic impact. Suppression overcame the pandemic more quickly but brought extreme economic consequences because of disruption in Aggregate supply and demand. However, the hope is that the economy can recover more quickly as long as there is no increase in the number of cases exposed to pandemics. It should be noted that a pandemic tends to have a period of 18 months until the vaccine is available.

The choice of disease management that will be taken, whether mitigation or suppression, causes different economic consequences. Mitigation, which takes living with pandemic longer, has a less bad impact on the economy. It is estimated only to negatively impact aggregate demand but less impact aggregate supply because the population will not be fully locked down. In other words, depression (deflation and recession) is most likely to occur due to mitigation. If the government chooses to suppress a pandemic, 
as China does, especially in Hubei province, supply shocks happened and maybe greater because most businesses and jobs that require physical presence cannot be carried out in full lockdown. In this situation, aggregate supply and demand are disrupted. In that context, stagflation (inflation and high recession) is the most likely scenario.

\section{Macroeconomic Policy for Overcoming}

Economic policy is carried out to present a V-shape in economic recovery, where economic growth is recovering at least the same level before the pandemic. The economic policies undertaken for economic recovery consist of two items: first, measures for locking the spread of COVID-19. These measures aim to stop negative AS shocks. Second, fiscal and monetary policy stimulus to shift the aggregate demand curve to the right (see panel $\mathrm{c}$ at Figure 1). This stimulus is to accelerate recovery from the economic crisis. These actions were carried out by all countries affected by the pandemic (Baldwin \& Di Mauro, 2020).

Measures and policies as stated above, have been carried out by many countries in the world, including Indonesia, namely 1) prevention of the spread of COVID-19 (lockdown, rapid and massive test, travel band/ restriction, physical distancing, working from home, a study from home, prohibiting public activities and penalties for noncompliance), 2 Allocating public expenditure for public health infrastructure and facilities like emergency hospital space, ventilators, protective medical equipment, medical personnel; 3) measures to subsidize or support income for workers who are forced to lay off or the unemployed 4) general or targeted cash transfers; 5) Assisting affected business, e.g. wage subsidies, tax cuts, moratoriums on debt repayments, credit lines, and 5) reduced stress on financial systems; interest rate cuts, reduced reserved requirements, lower rates and longer maturity on the discount window (Loayza and Pennings, 2020); Kementerian Keuangan, 2020; and Baldwin \& Di Mauro, 2020)).

Some other essential actions need to be taken during a health crisis (when the outbreak starts until the situation shows a decline in the number of infection cases). The first action at the national level, i.e., First, a proactive management approach and collaboration among stakeholders, including government, media, NGOs, the community, health professionals, and individuals, is vital in overcoming this pandemic problem (Evans, 2020; Zhao et al., 2020). Second, authentic, transparent, open, and accurate data avoid the occurrence of either an attitude of underestimation or excessive concern to the pandemic, which makes economic loss get worse (Gong et al., 2020). Third, the success of overcoming the health crisis is necessary because, in the case of a pandemic, this health crisis implies presenting an economic crisis. Therefore, actions that overcome the health crisis must involve competent experts who deeply understand the pandemic and the virus itself. Learning from the failure of China's early warning system to prevent COVID-19 from becoming an epidemic that caused a global outbreak of CORONA lies in their epidemic governance system dominated by bureaucracy and politicians. While the scientific/professional community's capacity in this regard, such as virologists, doctors, 
and epidemiologists, are ignored. This condition is one of the main factors contributing to the virus outbreak's damage early warning system in China ( $\mathrm{Gu} \& \mathrm{Li}, 2020)$. Fourth, in the future, the importance of providing health care infrastructure and vaccines for anticipating other kinds of new epidemics or pandemics (Paget, 2009).

In international cooperation, containment of the spread of viruses that are not internationally coordinated will increase the likelihood of a repeated outbreak across the world. This condition means repeated locking of the virus is needed and will have implications for larger fatalities and greater economic losses (Kohlscheen et al., 2020; Loayza \& Pennings, 2020; McKibbin \& Fernando, 2020).

Economic policies must be carried out internationally among countries and territories (Kohlscheen et al., 2020; Loayza \& Pennings, 2020). International policy cooperation is needed to improve monetary and fiscal stimulus effectiveness at the national level and avoid beggar-thy-neighbor policies such as competitive devaluation. According to Herrero (2020), international macroeconomic policy cooperation for overcoming the current economic crisis nowadays is more important than during the 2008 financial crisis for several reasons; First, the shock to the real economy is greater than the global financial crisis of 2008, considering that more than 200 countries are directly affected by COVID-19. Second, the COVID-19 pandemic attacks the real economy's heart, i.e., the company's cash flow and household income. Third, the non-banking portion of the financial system has become huge and does not directly access central bank liquidity. Fourth, the global financial system is more interrelated than in the past. For Indonesia, the cooperation and coordination of macroeconomic policies to overcome the COVID19's economic crisis are essential. Because economic liberalization has caused financial sectors (from both domestic and foreign) to be the most significant source of economic instability in Indonesia (Irawan \& Warjiyo, 2005) thus, to overcome the impact of instability stemming from the globalization of COVID-19 cannot rely solely on the strength of domestic economic policy.

\section{Conclusion}

This study provides the following conclusions: firstly, the aggregate supply shock is the initial impact of a pandemic. Then there is a mutual effect between shock aggregate supply and demand. In the short-run equilibrium condition, the impact of the negative shock in both AD and AS causes an economy to achieve a situation where GDP (output) is below (smaller) than full-employment output, and the price level is lower than the full-employment price level. This condition means the short-run economy's economy has a lower national output (income) coupled with deflationary pressure. If this phenomenon continues, it will create an economic recession.

Secondly, economic policies in the pandemic intend to increase public health care capacity and provide incentives for the people to comply with all activities that can lock down the spread of the virus. Meanwhile, the pandemic aftermath measures are carried out to contain the virus spread through social distancing until the vaccine is found to 
prevent further waves of outbreaks and accelerate economic recovery by executing fiscal and monetary stimulus.

Thirdly, measures for containment of the virus spread and execution of fiscal and monetary stimulus should be coordinate internationally among countries and territories. Unilateral action has a great chance of failing to overcome the economic crisis due to a pandemic. Locking the spread of not coordinated viruses will increase the likelihood of wider and repeated the pandemic outbreak. International macro policy cooperation is needed to increase monetary and fiscal stimulus policies carried out at the national level.

\section{References}

Arnold, R., De Sa, J., Gronniger, T., Percy, A., \& Somers, J. (2006). A Potential Influenza Pandemic: Possible Macroeconomic Effects and Policy Issues. Retrieved from: https:// www.cbo.gov/sites/default/files/109th-congress-2005-2006/reports/12-08-birdflu.pdf.

Asian Development Bank. (2020). The Economic Impact of the COVID-19 Outbreak on Developing Asia. ADB Briefs No. 128. Manila: Asian Development Bank.

Baldwin, R., \& Di Mauro, B. W. (Eds.). (2020). Economics in the Time of Covid-19. London: CEPR Press.

Bank of Spain. (2020). Reference Macroeconomic Scenarios for the Spanish Economy After COVID-19. Economic Bulletin, 2, 1-32.

Barro, R. J., Ursúa, J. F., \& Weng, J. (2020). the Coronavirus and the Great Influenza Pandemic. NBER Working Paper Series (No. 26866). Cambridge.

Barua, S. (2020). Understanding Coronanomics: The economic implications of the coronavirus (COVID-19) Pandemic. MPRA Working Paper No. 99693.

Boissay, F., \& Rungcharoenkitkul, P. (2020). Macroeconomic Effects of Covid-19: An Early Review. BIS Bulletin, 7, 1-9. Retrieved from https:/www.bis.org/publ/ bisbull07.htm

Correia, S., Luck, S., \& Verner, E. (2020). Pandemics Depress the Economy, Public Health Interventions Do Not: Evidence from the 1918 Flu. SSRN Electronic Journal, 1-56. https://doi.org/10.2139/ssrn.3561560

Crotty, J. (2009). Structural Causes of The Global Financial Crisis : a Critical Assessment of The "New Financial Architecture". Cambridge Journal of Economics, 33, 563-580. https://doi.org/10.1093/cje/bep023

Eichenbaum, M., Rebelo, S., \& Trabandt, M. (2020). The Macroeconomics of Epidemics. NBER Working Paper No. 26882. https://doi.org/10.3386/w26882.

Evans, O. (2020). Socio-Economic Impacts of Novel Coronavirus: The Policy Solutions. Bizecons Quarterly, 7, 3-12.

Fan, V., Jamison, D., \& Summers, L. (2016). The Inclusive Cost of Pandemic Influenza Risk. NBER No. 22137. https://doi.org/10.3386/w22137

Gong, B., Zhang, S., Yuan, L., \& Chen, K. Z. (2020). A Balance Act: Minimizing Economic Loss While Controlling Novel Coronavirus Pneumonia. Journal of 
Chinese Governance, 5(2), 249-268. https://doi.org/10.1080/23812346.2020.1 741940

GPMB, G. P. M. B. (2019). A World at Risk: Annual Report on Global Preparedness for Health Emergencies. Retrieved from: https:/lapps.who.int/gpmb/assets/annual_report/ GPMB_annualreport_2019.pdf

Gu, E., \& Li, L. (2020). Crippled Community Governance and Suppressed Scientific/ Professional Communities: a Critical Assessment of Failed Early Warning for The COVID-19 Outbreak in China. Journal of Chinese Governance, O(0), 1-18. https:// doi.org/10.1080/23812346.2020.1740468

Herrero, A. G. (2020). The Pandemic Requires a Coordinated Global Economic Response. Intereconomics, 55(2), 66-67. https://doi.org/10.1007/s10272-020-0871-7.

Irawan, A. (2005). Analisis Keterkaitan Ekonomi Makro, Perdagangan Internasional dan Pertanian di Indonesia: Aplikasi Vector Error Correction Model. (Unpublished Dissertation). Bogor: IPB University.

Irawan, A., \& Warjiyo, P. (2005). Analisis Perilaku Instabilitas Perkonomian Indonesia: Pendekatan Keterkaitan Ekonomi Makro, Perdagangan Internasional dan sektor pertanian. Buletin Ekonomi Moneter Dan Perbankan, 8(3), 291-330.

Jordà, Ò., Singh, S. R., \& Taylor, A. M. (2020). Longer-run Economic Consequences of Pandemics. NBER Working Paper No. 26934. Cambridge.

Kementerian Keuangan. (2020). Konferensi Pers Perkembangan Makro dan Asumsi Dasar Ekonomi Tahun 2020. Jakarta: Kemenkeu

Kementerian Keuangan. (2020). Press Conference Langkah Penguatan Perlindungan Sosial dan Stimulus Ekonomi Menghadapi Dampak Covid-19. Jakarta: Kemenkeu.

Kohlscheen, E., Mojon, B., \& Rees, D. (2020). The Macroeconomic Spillover Effects of the Pandemic on the Global Economy. SSRN Electronic Journal, 4, 2-11. https:// doi.org/10.2139/ssrn.3569554

Lee, J.-W., \& Mckibbin, W. J. (2004). Globalization and Disease: The Case of SARS. Brookings Discussion Papers in International Economics, No. 156.

Loayza, N. V, \& Pennings, S. (2020). Research \& Policy Briefs Macroeconomic Policy in the Time of COVID-19: A Primer for Developing Countries. Research and Policy Briefs No. 28. Washington DC: World Bank.

Lucchese, M., \& Pianta, M. (2020). The Coming Coronavirus Crisis: What Can We Learn? Intereconomic, 55, 98-104. https://doi.org/10.1007/s10272-020-0878-0

Marty, A. M., \& Jones, M. K. (2020). The Novel Coronavirus (SARS-CoV-2) is a One Health Issue. One Health, 9, 100123. https://doi.org/10.1016/j.onehlt.2020.100123

McKibbin, W., \& Fernando, R. (2020). The Global Macroeconomic Impacts of COVID-19: Seven Scenarios. CAMA Working Paper No. 19/2020.

Paget, J. (2009). The influenza pandemic and Europe: The Social impact and public health response. Italian Journal of Public Health, 6(3), 257-259. https://doi. org/10.2427/5781 
Sachs, M. (2020). Macro-Fiscal Considerations in Response to the COVID-19 Crisis. Retrieved from: https://covid19economicideas.org/wp-content/uploads/2020/04/ MacroFiscalStrategy_in_Covid19_Sachs_07042020-1.pdf.

Szlezak, P. C., Reeves, M., \& Swartz, P. (2020). Understanding the Economic Shock of Coronavirus. Harvard Business Review. Retrieved from: https://hbr.org/2020/03/ understanding-the-economic-shock-of-coronavirus

World Bank. (2014). The Economic Impact of the 2014 Ebola Epidemic: Short and Medium Term Estimates for West Africa. World Bank Report. Washington DC: World Bank.

World Bank. (2020). Assessing The Economic Impact of Covid-19 and Policy Responses in Sub-Saharan Africa. Africa's Pulse, 21. Washington DC: World Bank.

Zhao, W., Zhang, J., Meadows, M. E., Liu, Y., Hua, T., \& Fu, B. (2020). A Systematic Approach is Needed to Contain COVID-19 Globally. Science Bulletin, 65(11), 876-878. https://doi.org/https://doi.org/10.1016/j.scib.2020.03.024 